\title{
THE NATURE CONSERVANCY
}

$\mathrm{A}^{\mathrm{B} O \mathrm{~N}^{2}}$ OUT one-third of the fifteenth annual roport of the Nature Conservancy*, covering the year ended September 30, 1964, is again occupied by brief accounts of scientific research in progress, but some further scientific work is described in the account of the Scientific Advisory Services, for example, the work on grey seals and fisheries (on which the Consultative Committee on Grey Seals and Fisheries arranged a sciontific symposium on September $9,1964)$. Roforence is also made in that section of the report to the establishment of a Biological Records Centre at Monks Wood Experimental Station, using as a nucleus the Botanical Society's records and data-processing machinery. (The work of the Scientific Advisory Services and the conservation work are considered on p. 631 of this issue of Nature.)

During the year, $\$ 104,297$ was spent on research, studentships, training and special survoys, and $£ 81,073$ of this went to grants for research, studentships and training.

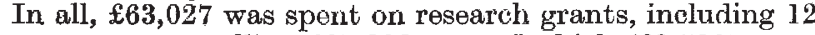
new grants totalling $£ 27,282$, one of which $(£ 9,500)$ went to the Wildfowl Trust towards the building and oquipping of one floor of the Trust's new research centre at Slim. bridge. Renewed grants included an interim $£ 9,500$ to the British Trust for Ornithology for investigations on bird populations and migration.

The Merlewood Research Station and the Moor House Field Station are now closely integrated and there is increasing collaboration with universities. The woodland botanists, who are mainly concerned with investigations on low-level oak woodlands, are now examining the nutrition of trees at $1,800 \mathrm{ft}$. at Moor Houso, and the investigations will provido important information on the possibilities of growing trees, not necossarily for the production of economic timber, but as ecological tools for the proper utilization of hill-land. Much attention is being directod to the circulation of mineral nutrients within the woodland and moorland ecosystem, including an examination of the rate at which nitrogenfixing organisms can supplement the input by rain and so restore the major depletion of nitrogen - some 70 per cent whon moorland vegetation is destroyed by burning.

Research at Furzebrook is concentrated on populations and physiography, including hydrology. The distribution survey of the Dorset heath (Erica ciliaris) has been completed and further sites selected for investigation. $\Lambda$ stratigraphical and ocological examination of the valley bogs in Dorsot has been started, including a detailed survey at Morden Bog National Nature Reserve, where pitfall trapping of spiders continued and was started at Studland Heath National Nature Reserve. A detailed historical investigation of the changing Spartina marsh pattern since the first appearance of the grass in Poole Harbour in 1900 has been completod. A detailed recent survey puts the area in Poole Harbour at about 1,700 acres, and it appears possible that the growth limits of marsh plants may be sensitive indicators of small-scale recent changes in sea-level. Investigations havo also been made on the physiography, tidal submergence and chlorinity of the salt marshes in Poole Harbour, and coastal research has been continued at Bridgwater Bay, Orfordness, Braunton Burrows and Dawlish Warren, including examination of the chronology of their evolution. A survey of water balance programmes was con. centrated on the peat uplands of the west and north and,

* Report of the Nature Conservancy for the year ended September 30, 1964. Pp. vii +173+10 plates. (Iondon: H.M.S.O., 1964.) 138. net. to a lesser extent, on the Woodwalton Fen area of Huntingdonshire.

At Monks Wood Experimental Station, work on moles (Talpa europea) commonced, particularly in Monks Wood and Woodwalton Fen. Detailed moasurements of seedling growth were made in the experimental blocks at Yarnor Wood, Monks Wood, Wychwood, Holme Fen and Castor Hanglands National Nature Reserves and the offects of various treatments are being assessed. Investigations by live trapping of populations of the bank vole (Clethrionomys ylareolus) and wood mouse (Apodemus sylvaticus) continued, and the programme of sampling the invertebrate fauna of two contrasting grass-heaths in the East Anglian Breckland has boen completed. The examination of the succossion of aquatic invertebrates in a dyke at Woodwalton Fen was continued, as well as those of tho changes in vegetation of a south-facing slope at old Winchester Hill as a result of sheep-grazing, and of the offect of sheep-grazing on the floristic composition of chalk grassland on the Barton Hills, Bedfordshire.

New work in the Toxic Chemicals and Wild Life Section includes examinations of the arthropod fauna of haw. thorn hedges in relation to the presence of associated herb species; of the plants and insects of roadside verges, with the view of providing a scientific basis for advice on tho conservation aspect of roadside maintenance; of the invasion of fields by selected weed species from hedges; and of the rate of destruction of hedges. Investigations on the distribution and size of organochlorine insecticide residues in mammals, birds, birds" eggs and invertebrates have been greatly helped by a gas chromatographic apparatus.

In May 1964 the research programme on red deer on Rhum was extended to cover the feoding ecology of the animal and thus establish a link with the investigation of vegetation production. The survey for the vegetation map of Rhum has been completed and it will now bo possible to estimate tho approximate acreages of the plant communities grazed by the red deer. Censuses were again mado throughout Orkney by the Grey Seals Research Officer, and examinations were made at breeding colonies in Colensay, on islands in the Sound of Harris and in Orkney and Shetland. The substantial winter mortality of adult Soay sheep on Hirta and of the subsequent lambing was investigated in March-May 1964. An investigation of the cology of birch in the Highlands has been started, while further improvements have been made in the techniques of collocting and extracting tho seeds of trees and shrubs for use on reserves. Investigations of red grouse (Lagopus lagopus scoticus) at Blackhall and Kerloch, Kincardineshire, have concentrated on behaviour and nutrition in relation to a long-term population examination. At the Speyside Research Station much of the research of the Climatological Section concerns the climatological aspects of productivity investigations, particularly the water balance and changes in air humidity. Research at the Bangor Research Station continues to be concerned with investigations in Snowdonia on the influence of variations in local climate and geology on soils, vegetation (particularly grasslands and related arctic-alpine communities) and biological productivity. An X-ray fluorescenco spectro. graphic mothod has been developed for the rapid analysis of the major elements in powdered rocks. Earlier studies of sheep population donsities and their growth have been extended to an investigation of the increment of plant 'dry matter' and energy by different plant communities in summer. 